\title{
De geldsluier; het jaarverslag van De Nederlandsche Bank 1987
}

\section{Inleiding}

In ouderwetse leerboeken van de economie kwam veelvuldig het beeld voor van de geldsluier, die over het reële gebeuren hing. Het ging er om, die sluier weg te trekken om te zien wat er eigenlijk aan de hand was.

Later is deze beeldspraak in onbruik geraakt. Het werd duidelijk dat het geld meestal veel meer dan een sluier was en dat het mede bepalend was voor het reële gebeuren.

Toch is er reden, dat oude beeld weer even op te roepen. Er is - zowel mondiaal als nationaal - weer iets van een geldgebeuren dat een eigen bestaan leidt en waarvan de reële sfeer zich weinig of niets aan trekt. Zo gaat wat de Verenigde Staten betreft de stijging van de economische activiteit nog ononderbroken door, ondanks beurskrach, zwakte van de dollar, gapend betalingsbalanstekort en aanhoudend groot financieringstekort van de federale overheid. Het volume van de wereldhandel blijft redelijk oplopen, ondanks de nog steeds niet opgeloste schuldenproblemen van vele ontwikkelingslanden.

In ons land gelukt het nog steeds niet, het financieringstekort van de overheid belangrijk terug te dringen, maar dat verhindert niet het verder oplopen van de economische activiteit, de gestadige terugdringing van de werkloosheid en het herstel van de bedrijfsinvesteringen.

Natuurlijk betekent dit niet dat het geld en de financiën plotseling onschuldig zijn geworden. Ieder ogenblik kan de reële sfeer toch weer worden aangetast door geldelijke of financiële onevenwichtigheden. We leven gevaarlijk. We krijgen een adempauze om financieel orde op zaken te stellen. Het kan niet blijvend goedgaan bij alles wat er in de financiële sfeer mis is. Met deze waarschuwing is ongeveer de teneur weergegeven van het laatste jaarverslag van De Nederlandsche Bank, waarvan met name het algemene overzicht zoals gebruikelijk in sterke mate de hand verraadt van president Duisenberg. In het volgende zal dan ook in hoofdzaak aandacht worden geschonken aan dit overzicht. Het gaat daarbij met name over wat er mondiaal, Europees en nationaal aan de hand is op de gebieden waar de president zich beweegt. Daarbinnen moet een keus worden gemaakt, zodat de behandeling in het volgende wordt toegespitst op enkele saillante punten. Daarvan is er éen dat in alle jaarverslagen van de laatste jaren grote aandacht krijgt: het taaie financieringstekort van de overheid in Nederland. 


\section{Mondiale aangelegenheden}

Ten aanzien van de Verenigde Staten zijn de beurskrach van oktober en de positie van de dollar toonaangevende gebeurtenissen en ontwikkelingen. Wat de president over de beurskrach schrijft komt er in hoofdzaak op neer dat die nu wel geacht kan zijn, te zijn verwerkt. De doorwerking op de reële sfeer is allemaal erg meegevallen. Het is een sanerende daling gebleven, vrijwel zonder verdere repercussies. Achteraf bezien lag dat ook voor de hand, want de oververhitting van de Amerikaanse aandelenmarkt die aan de instorting van de koersen voorafging had zich eveneens alleen in de effectensfeer voltrokken.

Het verder inzakken van de koers van de dollar daarentegen gaat niet langs de rest van het economische gebeuren heen. De Amerikaanse uitvoer wint als gevolg daarvan snel terrein op de voornaamste concurrenten en toch blijven de betalingsbalanstekorten op lopende rekening nog steeds hoog. De president wijst als verklaring op twee oorzaken. In de eerste plaats zijn de uitgangspunten asymmetrisch. De invoer is zoveel hoger dan de uitvoer dat de laatste naar verhouding uitzonderlijk sterk moet stijgen om sanerend te werken. Verder is de Amerikaanse conjunctuur zo hoog opgelopen dat de zuigkracht van de binnenlandse markt grenzen stelt aan de verdere toeneming van de uitvoer.

Over akkoorden betreffende stabilisatie van de dollar door interventie van centrale banken uit de president zich enigszins afstandelijk. Het is immers niet voor bestrijding vatbaar dat de dollar door het akkoord van Louvre heen is gezakt. Toch is hij van mening dat, daar er nu eenmaal voor de afzienbare tijd geen andere geldeenheid is die als reservevaluta kan optreden, de centrale banken de dollar niet helemaal aan zijn lot kunnen overlaten.

Het schuldenprobleem van een groot deel van de derde wereld blijft naar zijn oordeel een schaduw werpen over de wereldeconomie. De sanering gaat slechts uiterst langzaam. In eenzijdige moratoria ziet de president niets en evenmin gaat zijn voorkeur uit naar vergemakkelijking van de voorwaarden van het Internationale Monetaire Fonds. Integendeel komt het er op aan, de schuldenlanden te blijven bewegen, hun deel aan de nodige aanpassing te dragen.

\section{Europa}

Wat de Europese economische samenwerking en het Europese Monetaire Stelsel betreft kan de president er niet omheen, iets te zeggen over de mogelijkheden tot oprichting van een gemeenschappelijke Europese centrale bank. Is dit een vlucht naar voren of hebben deze plannen een zeker realiteitsgehalte? Men krijgt de indruk dat Duisenberg het voorlopig niet ziet zitten. Hij uit zich niet negatief, maar geeft enkele belangrijke voorwaarden aan. In de eerste plaats kan het financiële beleid dan niet meer aan de nationale overheden worden overgelaten. In de tweede plaats moet de autonomie van zulk een Europese centrale bank tegenover de politiek inhoudelijk bij verdrag worden geregeld. Die regelingen lopen thans binnen de Europese gemeenschap nogal uiteen. Ook zal het Verenigd Koninkrijk zich niet langer kunnen onttrekken aan het wisselkoersarrangement. 
Alleen het opsommen van deze voorwaarden is eigenlijk al afdoende. Met name staan we nog ver van de vervulling van de eerste en tweede af. Maar daarom kunnen de landen er zich best in gaan verdiepen. Wat de president daarbij vermoedelijk dacht was: 'Dan zullen ze vanzelf wel in de gaten krijgen hoe moeilijk het is.' Nog duidelijker kwam deze zienswijze tot uiting in een later gegeven commentaar op Westduitse plannen om vrij hard van stapel te lopen.

\section{Het binnengebeuren}

Met de vermindering van het financieringstekort van de overheid wil het nog niet erg. Tussen 1982 en 1987 is het als percentage van het nationale inkomen ternauwernood gedaald tot 9,2. Dat betekent dat Nederland zich nog ten volle in de gevarenzone bevindt.

Wat dit betreft gaat de president langzamerhand lijken op de man die in het bekende Engelse verhaal voortdurend roept dat er een wolf aankomt. Omdat de wolf steeds uitblijft wordt hem tenslotte geen geloof meer geschonken. Toen men er niet meer op verdacht was, kwam de wolf.

Die is er nu nog niet, maar valse gerustheid zou toch riskant zijn. Die gerustheid zou kunnen ontstaan doordat de onderliggende reële sfeer zich toch redelijk ontwikkelt. Er valt blijkbaar met een groot financieringstekort te leven. Zo kan zich een zekere bezuinigingsmoeheid vastzetten, uitgaande van de gedachtengang: het helpt toch niet en het geeft niet ook. Maar het geeft wel. De wolf ligt nog steeds op de loer.

Duisenberg geeft enkele punten aan waar bezorgdheid op haar plaats blijft.

In de eerste plaats lopen wij inzake het financieringstekort meer en meer uit de pas. Dat kan moeilijkheden geven bij de toenemende openheid van de Westeuropese economie die thans op stapel staat.

In de tweede plaats zijn averechtse gevolgen tot dusver uitgebleven omdat de internationale conjunctuur mee zat. Daar kunnen we niet op blijven rekenen. Maar zoals het nu is biedt de begroting geen enkele mogelijkheid, een economische inzinking te bestrijden.

We lopen ook langs de afgrond wat betreft het buitenlandse vertrouwen in ons land en in verband daarmee bevindt ons rentepeil zich in gevaar. Mede door in de komende jaren hoge aflossingsverplichtingen loopt de financieringsbehoefte van het rijk sterk op. Er moet dan voldoende vertrouwen bestaan in onze wil en mogelijkheid, financieel orde op zaken te stellen.

Dit betekent dat er naar het oordeel van de president veel meer zal moeten worden bezuinigd dan nu in de politieke sfeer is voorgenomen.

Eigenlijk is er helemaal nog niet bezuinigd. Het is dan ook niet toevallig dat tegenwoordig gesproken wordt van 'ombuigen' i.p.v. bezuinigen. De overheidsuitgaven stijgen alleen minder sterk dan anders het geval zou zijn geweest. Een kleine berekening leert dat de rijksuitgaven in de laatste 10 jaar ongeveer $3 \mathrm{maal}$ zo snel zijn gestegen als het nationaal inkomen (cijfers F.H.), terwijl toch wel niemand staande zal houden dat wij in 1977 op dit gebied nog als apen in de bomen leefden. Zo gezien moet er ook wat de mogelijkheden voor bezuiniging betreft nog heel wat te vinden zijn.

Is dit een standje voor de minister van Financiën? Die heeft het in ieder geval 
niet zo opgevat, want hij heeft naar aanleiding van het jaarverslag verklaard dat hij het standpunt van de president over de trage sanering van de overheidsfinanciën beschouwt als een steuntje in de rug.

De eerstgenoemde vat de priemende vinger van Duisenberg dus op als over zijn hoofd heen gericht op de 'spending departments' en meer in het algemeen op de politiek, waar de minister van Financiën, als enige waakhond tegen de wolf binnen het politieke kamp, voortdurend moet inbinden.

Tot zover lijkt het betoog van de president niet voor betwisting vatbaar. Op één punt is echter een kritische kanttekening mogelijk. Dat betreft zijn visie op lastenverlichting. Hij wil voorlopig alle ombuigingen en mogelijke meevallers gebruiken voor bestrijding van het financieringstekort en constateert uit dien hoofde met zorg dat ruim f 2 miljard uit zogenaamde belastingmeevallers gebruikt wordt voor lastenverlichting, krachtens het in het voorjaar van 1988 gesloten akkoord. Wil men inderdaad lastenverlichting, dan moet er blijkbaar volgens hem in diezelfde mate extra worden bezuinigd.

Op deze wijze wordt bestrijding van het financieringstekort vrijwel verabsoluteerd. Dat gaat toch wel erg ver. Vooral lastenverlichting in de persoonlijke sfeer spaart loonstijging uit en is daardoor gunstig voor de werkgelegenheid. $\mathrm{Nu}$ loonbeheersing niet meer in aanmerking komt is lastenverlichting eigenlijk nog het enige instrument dat de centrale overheid heeft voor de verwezenlijking van verdere loonmatiging.

Ook heeft Duisenberg weinig goede woorden over voor het Nederlandse streven, meer in de pas te komen met de Europese belastingtarieven. Anders dan het werkgelegenheidsargument vermeldt hij dit wel, maar hij wijst het af. Wij zijn daartoe volgens hem niet in staat, of alleen door op andere punten juist nog verder uit de pas te geraken.

Naast de overheidsfinanciering vraagt deze keer ook het financieringsprobleem van het bedrijfsleven de aandacht. In de loop van de jaren tachtig zijn de rendements- en vermogensverhoudingen fors verbeterd door loonmatiging, dalende rente, financiële investeringsfaciliteiten en betere afzetperspectieven. Onder deze omstandigheden liep de investeringsactiviteit vrij sterk op en konden bovendien nog schulden worden afgelost. Aan deze ontwikkeling is in 1987 weer een eind gekomen. Op transactiebasis kampt het bedrijfsleven zelfs weer met een financieringstekort. Er moet dus een toenemend beroep op externe financiering worden gedaan. Daar komt men dan vooral de staat tegen, als nog steeds gulzige kapitaalvrager. Hij zegt het niet met zoveel woorden, maar men zou hieruit kunnen lezen dat hij enige zorg koestert over de verdere ontwikkeling van het rentepeil. Wat dit betreft kan als een zekere geruststelling gelden dat in zijn beschouwing over het monetaire beleid melding gemaakt wordt van de beslissing, voor 1988 geen beperkingen meer voor te stellen voor de groei van het netto-geldscheppende bedrijf van de banken. Dat staat natuurlijk niet los van de gunstige ontwikkeling van de inflatie in ons land.

Wat betreft de afschaffing van de algemene toeslag krachtens de Wet Investeringsrekening krijgt men uit de bewoordingen van de president de indruk dat het van hem niet had gehoeven, maar hij legt er zich wel bij neer nu het vrijkomende geld geheel naar het bedrijfsleven terugvloeit. Zo ver zijnde, begroet hij in het hele pakket toch ook de toenadering tot het buitenland inzake het tarief van de vennootschapsbelasting, de vereenvoudiging die per 
saldo wordt bereikt en de daling van de arbeidskosten doordat het rijk de kinderbijslagpremie overneemt.

\section{Slotopmerkingen}

In zekere zin schrijft de president in de laatste jaren merkwaardige jaarverslagen. $\mathrm{Hij}$ is in eerste aanleg nauwelijks meer bezorgd over de zaken die in het bijzonder aan zijn hoede zijn toevertrouwd. Zelfs de liquiditeitsquote, die tevoren nog tot lichte ongerustheid aanleiding gaf, is nu wel in het gareel gekomen. Met vrijwel verdwenen inflatie, een sterke gulden, een niet weg te branden overschot op de betalingsbalans op lopende rekening, een herhaaldelijk verlaagd disconto, een kapitaalmarktrente die zelfs - mede door het voornemen tot een voorheffing op rente-inkomsten in de Bondsrepubliek onder de Westduitse is gekomen, zou Duisenberg zich vinger en duim moeten aflikken.

Alle economische grootheden waar hij vooral verantwoording voor draagt, doen het zo goed als maar kan. In de monetaire beschouwingen is dan ook geen enkele wanklank te vinden. Toch is het hele jaarverslag een stuk waarin het wenkbrauwfronsen overheerst, omdat de pret op afstand wordt bedorven door het hardnekkige financieringstekort. Op zichzelf kan hij zich dat nog van het lijf houden door het, behoudens in voorbijgaande gevallen, niet mee te financieren, maar doordat alles met alles samenhangt, zeker op monetair en financieel gebied, vormt het grote overheidslek een voortdurende bedreiging voor de dingen die nu juist voor de president van de centrale bank zo leuk zijn. Wat er, evenals in de reële sfeer, op monetair gebied nog allemaal goed gaat, is mooi meegenomen, maar het is verre van veilig gesteld. Deze combinatie van goed en slecht is in de tegenwoordige omstandigheden ook allemaal zo specifiek Nederlands, dat moeilijk denkbaar is hoe een Europese centrale bank hiermee uit de voeten zou kunnen. Maar, gelijk gezegd, zover is het naar alle waarschijnlijkheid nog lang niet. 